JURNAL PENDIDIKAN, p-ISSN 2715-095X, e-ISSN 2686-5041

Volume 29, No.1, Maret 2020 (45-56)

Online: http://journal.univetbantara.ac.id/index.php/ JP

\title{
Penerapan Pendekatan Komunikatif untuk Meningkatkan Motivasi dan Kemampuan Keterampilan Berbicara Materi Debat Siswa Kelas X IPS 1 SMA Negeri 1 Gemolong Tahun Pelajaran 2019/2020
}

\section{Giyono}

\author{
Guru SMA Negeri 1 Gemolong Kabupaten Sragen, Email: giyono1603@gmail.com
}

\begin{abstract}
Abstrak: Tujuan penelitian ini adalah untuk mendeskripsikan, menjelaskan pelaksanaan model pembelajaran pendekatan komunikatif dan dengan penerapan model pembelajaran tersebut untuk meningkatkan motivasi dan kemampuan berlatih praktik debat pada siswa kelas X IPS 1 SMA Negeri 1 Gemolong. Penelitian ini adalah penelitian tindakan kelas yang dilaksanakan dalam 2 siklus terdiri dari perencanaan, tindakan, pengamatan, dan refleksi. Subjek penelitian adalah siswa kelas X IPS1 SMA Negeri 1 Gemolong pada semester 1 tahun pelajaran 2019/2020. Sumber data diperoleh dari guru, siswa, tempat, dan peristiwa berlangsungnya aktivitas pembelajaran dan dokumentasi. Teknik dan alat pengumpulan data menggunakan observasi. Validitas data menggunakan trianggulasi sumber data. Analisis data menggunakan analisis kualitatif. Hasil penelitian menunjukkan bahwa sebelum tindakan penelitian kelas, ratarata kemampuan siswa berlatih praktik debat mendapat skor kurang memuaskan, setelah diadakan siklus I mendapat skor rata-rata 73,17 dan setelah siklus II rata-rata mendapat skor 84,15 , Sementara aktivitas siswa dalam pembelajaran berlatih praktik debat juga meningkat setiap pertemuan pada siklusnya, siklus I rata-rata 70, siklus II rata-rata 95. Berdasarkan hasil observasi kinerja guru juga mengalami peninglatan sehingga hal tersebut mempengaruhi kemampuan berlatih praktik debat pada siswa kelas X IPS 1 SMA Negeri 1 Gemolong. Berdasarkan hasil penelitian di atas, dapat disimpulkan bahwa penerapan pendekatan komunikatif dapat meningkatkan motivasi dan kemampuan berlatih praktik debat pada siswa Kelas X IPS 1 Semester 1 SMA Negeri 1 Gemolong Tahun Pelajaran 2019/2020. .
\end{abstract}

Kata-kata Kunci : Metode komunikatif, meningkatkan motivasi dan kemampuan, berbicara

\section{The Implementation of Communicative Approach Increased Motivation Speaking Skills Debate Material in Learner Class X IPS 1 SMA Negeri 1 Gemolong in the Academic Year of 2019/2020}

Giyono

\author{
The Tacher of SMA Negeri 1 Gemolong Sragen
}

\begin{abstract}
The purpose of this research is to describe, explain implementation of communicative approach learning model and with that learning model application to increase motivation and practicing practice debate ability for the student of X IPS 1 SMA Negeri 1 Gemolong. This research is class action research which executed in 2 cycles and every meeting consist of planning, action, observation, and reflection. This subject of research is the students of XIPS 1 SMA Negeri 1 Gemolong at semester 1 period 2019/2020. Data source is obtained by teacher, student, place, and learning activity and documentation event be heading. Technique and data's gathering divide use observation. The data's validity uses data source triangulation. Data's analysis uses qualitative analysis. The result of research indicates that before the class research action, the student's ability to practicing practice debate to reach less satisfactory, after cycle I is held, getting average score 73,17 and after cycle II average get score 84,15, white being active in practicing practice debate learning also increasing in every meeting at the cycle, averaging cycle $I$ is 70, averaging cycle II is 95. Based on the result of teacher's
\end{abstract}


performance observation also increasing until that influence the student's practicing practice debate ability, especially the student's of XIPS 1 SMA Negeri 1 Gemolong. Based on the result of research above, we can conclude that application of communicative methods can increasing motivation to practicing practice debate and increasing ability the student's of X IPS 1 semester 1 SMA Negeri 1 Gemolong, in period 2019/

Key words: communicative methods, motivation and ability increase, speak up.

\section{Pendahuluan}

Menyimak dan berbicara merupakan kegiatan berbahasa lisan. Keduanya berkaitan dengan bunyi bahasa. Dalam menyimak, seseorang mendapat informasi melalui ucapan. Dalam berbicara, seseorang menyampaikan informasi melalui suara atau bunyi bahasa. Menyimak dan berbicara adalah dua kegiatan yang tak terpisahkan. Keterampilan berbicara menunjang keterampilan berbahasa lainnya. Pembicara yang baik memberikan contoh yang dapat ditiru oleh penyimak yang baik. Pembicara yang baik memudahkan penyimak untuk menangkap pembicaraan yang disampaikan. Keterampilan berbicara menunjang pula keterampilan menulis sebab pada hakikatnya antara berbicara dan menulis, terdapat persamaan dan perbedaan. Dua-duanya bersifat produktif dan juga berfungsi sebagai penyampai, penyebar informasi. Bedanya terletak dalam media. Bila berbicara menggunakan media bahasa lisan, maka menulis menggunakan bahasa tulisan. Keterampilan menggunakan bahasa lisan akan menunjang keterampilan bahasa tulis. Begitu juga kemampuan menggunakan bahasa dalam berbicara jelas pula bermanfaat dalam memahami bacaan. Apalagi dalam cara mengorganisasikan isi pembicaraan hampir sama dengan cara mengorganisasikan isi bacaan. Siswa dalam mengikuti pembelajaran dituntut agar dapat berbicara. Mereka harus dapat mengutarakan pertanyaan-pertanyaan. Mereka harus dapat mengutarakan kemampuannya dalam berbagai hal melalui berbagai cara pula. Pembelajaran berbahasa dapat dikatakan setua usia manusia hidup berkelompok dan menggunakan bahasa sebagai alat komunikasi. Bahasa itu kemudian dilestarikan. Salah satu pelestarian itu melalui pembelajaran bahasa pada keluarga dan masyarakat. Sifat pembelajaran dalam masyarakat tradisional itu biasanya bersifat tradisional. Oleh karena itu dapat dinyatakan bahwa pembelajaran berbahasa yang tertua bersifat lisan yang pada umumnya berlangsung dalam keluarga. Dalam pendidikan formal, pembelajaran bahasa sudah lama termasuk ke dalam kurikulum sekolah. Tujuan pembelajaran di sekolah sering berubah mengikuti tuntutan dan kebutuhan masyarakat. Tujuan perubahan pembelajaran bahasa itu menimbulkan corak pembelajaran dan materi yang berubah-ubah pula. Kadangkadang pengajaran bahasa mengarah pada segi pengetahuan. Kini pembelajaran bahasa cenderung pada keterampilan berbahasa. Keadaan pembelajaran berbicara, sejalan dengan keadaan pembelajaran bahasa Indonesia, belum memuaskan. Keterampilan berbicara, dalam arti luas, para pelajar belum memadai. Kenyataan dalam diskusi, seminar ataupun ceramah menunjukkan bahwa sebagian besar pesertanya diam, kurang bersuara. Kecakapan beradu argumentasi apalagi masih jauh dari memadai (Tarigan, 1986:88). Berdasarkan hasil studi pendahuluan melalui wawancara dengan guru mata pelajaran Bahasa Indonesia di SMA Negeri 1 Gemolong diperoleh keterangan bahwa, hasil tes siswa kelas X IPS 1 dalam Pembelajaran Berbicara, masih rendah. Sebanyak 60\% dari 36 orang siswa belum mampu berbicara dengan baik. Jadi, nilai sebagian siswa masih tergolong rendah dari nilai rata-rata yang dicapai dalam mata pelajaran bahasa Indonesia yaitu 75. Hasil wawancara dengan siswa, diperoleh kenyataan bahwa $75 \%$ siswa merasa bosan melakukan pembelajaran bahasa Indonesia karena sikap guru yang monoton dan materi yang diajarkan tidak variatif. 
Salah satu penyebab munculnya masalah tersebut diduga adalah faktor model yang digunakan kurang menarik. Upaya yang akan dilakukan untuk mengatasi masalah tersebut adalah melaksanakan pembelajaran dengan pendekatan komunikatif.

Berdasar latar belakang tersebut maka perlu diadakan perbaikan pembelajaran berbicara dengan mengoptimalkan efek pendekatan komunikatif. Metode pembelajaran merupakan cara yang dipergunakan oleh guru dalam berhubungan dengan siswa selama berlangsungnya pembelajaran. Dan akhirnya pembelajaran akan bermakna bagi proses belajar siswa dan berhasil mengantarkannya pada hasil belajar yang diharapkan. Penggunaan beberapa metode dalam pembelajaran harus sesuai dengan materi yang ada. Adapun materi yang dibahas dalam penelitian ini adalah berlatih praktik debat. Agar materi mudah dipahami oleh siswa maka perlu penyajian dan pembahasan dengan menggunakan metode / pendekatan komunikatif. Dengan pendekatan ini maka akan memberi waktu yang lebih banyak berpikir dan salig membantu satu sama lain sehingga siswa lebih aktif dalam pembelajaran. Dengan harapan pembelajaran dapat berpengaruh positif terhadap hasil belajar yang dicapai oleh siswa. Perumusan masalah di dalam penelitian ini adalah bagaimanakah langkah-langkah pelaksanaan pembelajaran berbicara dengan menggunakan pendekatan komunikatif, dan bagaimanakah peningkatan kemampuan siswa setelah mengikuti pembelajaran berbicara dengan menggunakan pendekatan komunikatif. Pada dasarnya penelitian ini diharapkan dapat berhasil dengan baik, yaitu dapat mencapai tujuan penelitian secara maksimal dan menghasilkan laporan yang sistematis. Adapun manfaat yang dapat diambil dari penelitian ini bagi siswa dapat memperoleh kesempatan memperbaiki dan meningkatkan proses dan hasil belajar. Siswa dapat memperoleh pengetahuan dan pengalaman yang kompetitif dalam berbicara melalui pengembangan kreativitas ide yang mendasarinya berdasarkan ketentuan langkah belajar yang digunakan dalam pendekatan komunikatif.. Sedangkan bagi guru yakni untuk memperoleh memperbaiki dan meningkatkan kinerjanya melalui tindakan terencana dan terkorektif secara kolaboratif, memperoleh pengetahuan dan pengalaman yang sangat dipentingkan untuk menyetabilkan sikap mental dan spiritual sebagai penyeimbang tuntutan tugasnya yang kompleks, terutama mengajar yang membelajarkan, dan mendapat pencerahan dalam praktik mengajar yang membelajarkan siswa binaannya.Hampir dapat dipastikan bahwa dalam kehidupan kita sehari-hari tidak terlepas dari kegiatan berbicara atau berkomunikasi antara seseorang atau satu kelompok dan kelompok yang lain. Berbicara ialah kemampuan yang kompleks yang sekaligus melibatkan beberapa aspek. Aspek-aspek itu beragam dan perkembangannya pun seiring perubahan dan pergantian masa sehingga mengakibatkan berbeda, dengan kecepatan perkembangan yang berbeda pula. Secara garis besar, kegiatan berbicara dapat dibagi atas dua pilihan, pertama, berbicara di muka umum pada masyarakat (public speaking) atau berbicara individual. Kedua, berbicara pada konferensi (conference speaking) atau berbicara kelompok yang meliputi: (1) seminar kelompok baik formal maupun tidak formal; (2) prosedur parlementer; dan (3) debat. (Tarigan, 1986: 22-23). Jadi dapat disimpulkan bahwa yang dimaksud dengan berbicara dalam keperluan akademik atau ilmiah ialah berbicara dalam lingkungan akademik atau lembaga pendidikan berlandaskan pada hal-hal yang bersifat ilmiah atau ilmu pengetahuan misalnya presentasi makalah, seminar, simposium, dan panel. Dalam kegiatan ilmiah, Corak bahasa yang kita pakai harus bersifat reproduktif, impersonal, dan baku.

Banyak sekali para ahli psikologi pendidikan dan psikologi perkembangan yang membahas tentang motivasi dalam pembelajaran. Sedemikian banyaknya pembahasan tentang motivasi dalam pembelajaran itu telah menghasilkan definisi motivasi yang banyak 
pula. Namun demikian pada intinya, motivasi dapat diartikan sebagai (1) Dorongan yang timbul pada diri seseorang, secara disadari atau tidak disadari, untuk melakukan suatu tindakan dengan tujuan tertentu. (2) Usaha-usaha yang dapat menyebabkan seseorang atau kelompok orang tertentu tergerak melakukan sesuatu karena ingin mencapai tujuan yang ingin dicapai( Mohammad Asrori, 2007). Mulyasa (dalam Giyono, 2019 : 3) mengatakan bahwa motivasi adalah tenaga pendorong atau penarik yang menyebabkan adanya tingkah laku ke arah suatu tujuan tertentu. Peserta didik akan bersungguh-sungguh karena memiliki motivasi yang tinggi. Seorang siswa akan belajar bila ada faktor pendorongnya yang disebut motivasi. Dimyati dan Mudjiono (2002: 80) mengutip pendapat Koesworo mengatakan bahwa siswa belajar karena didorong kekuatan mental, kekuatan mental itu berupa keinginan dan perhatian, kemauan, cita-cita di dalam diri seorang terkadang adanya keinginan yang mengaktifkan, menggerakkan, menyalurkan dan mengarahkan sikap dan perilaku individu dalam belajar. Jadi dapat disimpulkan bahwa motivasi belajar adalah keseluruhan daya penggerak di dalam diri peserta didik yang menimbulkan kegiatan belajar menjamin kelangsungan dan memberikan arah pada kegiatan belajar sehingga tujuan yang dikehendaki dapat tercapai. Dalam motivasi belajar dorongan merupakan kekuatan mental untuk melakukan kegiatan dalam rangka pemenuhan harapan dan dorongan dalam hal ini adalah pencapaian tujuan.

Kemampuan atau kompetensi adalah suatu pengetahuan, ketrampilan, dan nilai-nilai dasar yang direfleksikan dalam kebiasaan berpikir dan bertindak (Depdikbud, 2004: 5). Kemampuan atau kompetensi adalah suatu ketrampilan untuk mengeluarkan sumber daya bakat atau internal dalam diri seseorang yang dapat memberikan manfaat bagi diri sendiri maupun orang lain. Pada hakikatnya setiap manusia mempunyai kemampuan yang dibawa sejak lahir. Kemampuan terus berkembang dan berproses sesuai dengan bertambahnya usia seseorang. Kemampuan atau kompetensi seseorang tidak akan berkembangang dengan baik kalau tidak disertai dengan usaha yang terus menerus. Kemampuan seseorang dapat berkembang dengan baik jika disertai dengan usaha yang sungguh-sungguh. Senada dengan hal tersebut, Mulyasa (2007: 215) menegaskan bahwa kompetensi yang harus dimiliki peserta didik perlu dinyatakan sedemikian rupa agar dapat dinilai, sebagai wujud hasil belajar yang mengacu pada pengalaman langsung. Kemampuan belajar digunakan untuk menyebutkan kemampuan individu yang berfungsi dalam lingkungan yang membutuhkan suatu usaha yang bersifat kognitif. Setiap kompetensi harus merupakan perpaduan dari pengetahuan, keterampilan, nilai, dan sikap yang direfleksikan dalam kebiasaan berpikir dan bertindak (Mulyasa, 2007: 215). Pendekatan komunikatif mengarahkan pembelajaran bahasa pada tujuan pengajaran yang mementingkan fungsi bahasa sebagai alat komunikasi (Imam Syafi'ie, 1993:17).Pendekatan komunikatif memfokuskan pada keterampilan siswa mengimplementasikan fungsi bahasa (untuk berkomunikasi) dalam pembelajaran. Berdasarkan prinsip pendekatan komunikatf, pengajaran berbicara harus diarahkan pada penggunaan bahasa dalam kehidupan seharihari. Pendekatan komunikatif adalah pendekatan dalam pembelajaran bahasa yang menekankan pada kemampuan berkomunikasi dan berinteraksi dalam situasi keseharian. Ada beberapa pendapat tentang pengertian pendekatan komunikatif. Penguasaan secara naluri yang dipunyai seorang penutur asli untuk menggunakan dan memahami bahasa secara wajar dalam proses berkomunikasi atau berinteraksi dan dalam hubungannya dengan konteks sosial (Dell Hymes, 1974). Bisa juga pendekatan yang mengintegrasikan pengajaran fungsi-fungsi bahasa dan tata bahasa. Pendekatan yang mendasarkan 
pandangannya terhadap penggunaan bahasa sehari-hari secara nyata (M. Soenardi Djiwandono, 1996).

Dari pendapat-pendapat di atas tampaknya pendekatan komunikatif ingin ditekankan fungsi bahasa sebagai alat komunikasi dalam proses interaksi antarmanusia. Komunikasi di sini juga bisa berupa komunikasi lisan maupun tertulis. Bahasa komunikatif selalu melekat pada berbagai hubungan dengan dunia. Berkenaan dengan prosedur pembelajaran dalam kelas bahasa yang berdasarkan pendekatan komunikatif, Finochiaro dan Brumfit (dalam Azies, 1996), menawarkan garis besar kegiatan pembelajaran untuk tingkat sekolah menengah pertama. Garis besar tersebut sebagai berikut. a) Penyajian Dialog Singkat ; Penyajian ini didahului dengan pemberian motivasi dengan cara menghubungkan situasi dialog dengan pengalaman pembelajaran dalam kehidupan seharihari. b)Pelatihan Lisan Dialog yang Disajikan ; Pelatihan ini diawali dengan contoh yang dilakukan oleh guru. Para siswa mengulang contoh lisan gurunya, baik secara bersamasama, setengah, kelompok kecil, atau secara individu. c) Tanya-Jawab ; Hal ini dilakukan dua fase. Pertama, tanya-jawab yang berdasarkan topic dan situasi dialog. Kedua, tanyajawab tentang topik itu dikaitkan dengan pengalaman pribadi siswa. d) Pengkajian; Siswa diajak untuk mengkaji salah satu ungkapan yang terdapat dalam dialog. Selanjutnya, para siswa diberi tugas untuk memberikan contoh ungkapan lain yang fungsi komunikatifnya sama. e) Penarikan Simpulan ; Siswa diarahkan untuk membuat simpulan tentang kaidah tata bahasa yang terkandung dalam dialog.

Kerangkaberpikir dalam penelitian ini dapat diterangkan dengan menempuh langkahlangkah sesuai dengan teori yang telah ditentukan. Langkah-langkah dimaksud sebagaimana dikemukakan Aqib (2013:24) berikut: (1) guru membagi dua kelompok peserta debat yang satu pro dan kontra, (2) guru memberikan tugas untuk membaca materi yang akan didebatkan oleh kedua kelompok di atas, (3) setelah selesai membaca materi, guru menunjuk salah satu anggota kelompok pro untuk berbicara saat itu ditanggapi atau dibalas oleh kelompok kontra demikian seterusnya sampai sebagian besar siswa bisa mengemukakan pendapatnya, (4) sementara siswa menyampaikan gagasannya, guru menulis inti/ide-ide dan setiap pembicaraan di papan tulis sampai sejumlah ide yang diharapkan guru terpenuhi, (5) guru menambahkan konsep/ide yang belum terungkap, (6) dari data-data di papan tersebut, guru mengajak siswa membuat kesimpulan/rangkuman yang mengacu pada topik yang ingin dicapai. Adapun peningkatan kemampuan siswa yang diharapkan setelah mengikuti proses pembelajaran berbicara dengan menggunakan pendekatan komunikatif antara lain: (1) mampu menentukan mekanisme diskusi; dan (2) mampu menyampaikan persetujuan, sanggahan, dan penolakan pendapat dalam diskusi dengan etika yang baik dan argumentatif. 


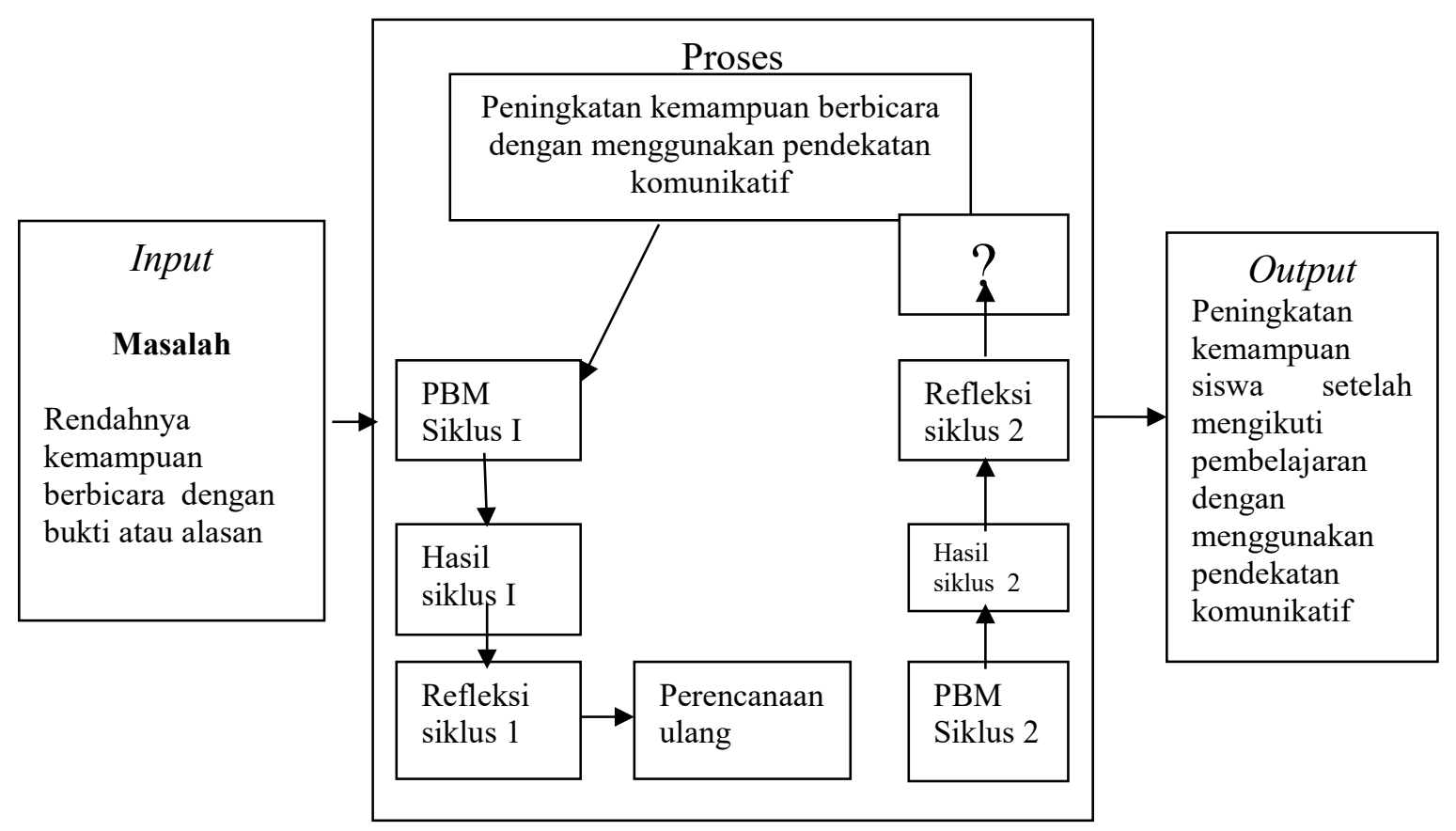

Gambar 1. Kerangka Berpikir

\section{Metode Penelitian}

Penelitian dilakukakan pdi SMA Negeri 1 Gemolong, Kabupaten Sragen yang beralamat di jalan Citrosancakan, Gemolong, Sragen. Sekolah ini mempunyai 28 kelas. Tindakan penelitian dilakukan di kelas X IPS 1 karena di kelas ini terdapat permasalahan yang perlu segera diatasi untuk memperbaiki proses dan hasil belajar bahasa Indonesia khususnya materi berbicara yakni berlatih praktik debat dan kebetulan penulis sebagai guru di kelas tersebut. Subyek penelitian ini adalah siswa kelas X IPS 1 SMA Negeri 1 Gemolong tahun pelajaran 2019/2020. Siswa di kelas tersebut berjumlah 36 orang, dengan laki-laki sebanyak 12 orang dan perempuan sebanyak 24 orang. Sedangkan obyek penelitiannya adalah motivasi dan kemampuan prestasi belajar. Pembelajaran berlatih praktik debat dengan menggunakan metode atau pendekatan komunikatif yang akan dilaksanakan berdasarkan Standar Kompetensi dan Kompetensi Dasar sesuai dengan kurikulum 2013 kelas X semester 2. Desain penelitian ini adalah suatu rangkaian tahaptahap penelitian dari awal sampai akhir. Pada model ini dalam setiap siklusnya menempuh empat tahapan kegiatan, antara lain: (1) perencanaan; (2) pelaksanaan; (3) pengamatan; dan (4) refleksi menurut Arikunto (dalam Triman 2017: 221).Adapun prosedur penelitian pembelajaran berbicara ini dengan menggunakan pendekatan komunikatif, adalah menempuh langkah-langkah sebagai berikut. 1) Tahap persiapan, meliputi; menyusun instrumen dan memvalidasinya, baik instrumen untuk perencanaan dan pelaksanaan pembelajaran berbicara dengan menggunakan pendekatan komunikatif; dan memahami perencanaan, pelaksanaan, prosedur dan bentuk pengukuran, serta penilaian dalam pembelajaran berbicara dengan menggunakan pendekatan komunikatif. 2) Tahap pelaksanaan, meliputi: mengadakan observasi terhadap proses pembelajaran berbicara dengan menggunakan pendekatan komunikatif; mengumpulkan data hasil observasi; menganalisis data hasil observasi; mendeskripsikan hasil analisis; danmembuat simpulan.3) Tahap akhir, meliputi:menyusun data hasil analisis ke dalam laporan hasil penelitian dan 
pembahasan;menjawab pokok permasalahan berdasarkan hasil pembahasan; melaksanakan bimbingan dan merevisi hasil klarifikasi; dan mempertanggungjawabkan hasil penelitian ini di hadapan sidang penguji. Sedangkan Teknik-teknik pengumpulan data dalam penelitian ini adalah: 1) Teknik Studi Pustaka; teknik ini digunakan untuk memperoleh gambaran tentang data, baik secara teoretis maupus secara praktis, yaitu melalui membaca berbagai buku yang berhubungan dengan penelitian. Instrumen yang digunakan adalah buku, jurnal, dan lain-lain, 2) Teknik Pembelajaran ; teknik ini digunakan dalam pembelajaran berbicara yang disajikan dengan menggunakan pendekatan komunikatif. Instrumen yang digunakan adalah lembar observasi, 3) Teknik Tes ; teknik ini digunakan untuk mengukur keberhasilan pembelajaran berbicara dengan menggunakan pendekatan komunikatif. Teknik tes yang digunakan, yaitu siswa terhadap materi yang telah disajikan. Instrumen yang digunakan adalah lembar tes, 4) Teknik Analisis ; teknik ini digunakan untuk menganalisis data yang sudah terkumpul melalui teknik-teknik pengumpulan data. Berikutnya untuk teknik analisis data yakni data yang sudah terkumpul, diolah dengan cara-cara sebagai berikut; 1) menganalisis kesesuaian data bentuk perencanaan pembelajaran berbicara dengan menggunakan pendekatan komunikatif dengan kriteria, kemudian hasilnya dideskripsikan, 2) menganalisis kesesuaian data pelaksanaan kegiatan pembelajaran berbicara dengan menggunakan pendekatan komunikatif, hasilnya kemudian dideskripsikan, 3) menganalisis prosedur, jenis dan bentuk pengukuran pembelajaran berbicara dalam dengan menggunakan pendekatan komunikatif, hasilnya kemudian dideskripsikan, 4) menganalisis perubahan kemampuan pada siswa dengan cara membandingkan hasil nilai prates dengan nilai pascates, hasilnya kemudian dideskripsikan.Penelitian dalam bentuk penelitian tindakan kelas ini dirancang dalam desain siklus yang masing-masing siklus memiliki tahapan-tahapan perencanaan, pelaksanaan, observasi dan reflkeksi. Pembelajaran dinyatakan selesai dalam siklus tertentu jika sudah mencapai KKM 75 yang diperoleh sekurang-kurangnya 75\% siswa.

\section{Hasil Penelitian}

Data penelitian yang diperoleh antara lain adalah data observasi berupa pengamatan pengelolaan pembelajaran berbicara dengan menggunakan pendekatan komunikatif dan pengamatan aktivitas siswa dan guru pada akhir pembelajaran, dan data hasil evaluasi setiap siklus. Data hasil observasi diambil dari dua pengamatan yaitu data pengamatan pengelolaan pendekatan komunikatif yang digunakan untuk mengetahui perubahan kemampuan berbicara dengan menggunakan pendekatan komunikatif dan data pengamatan aktivitas siswa dan guru. Data tes formatif untuk mengetahui peningkatan prestasi belajar siswa setelah diterapkan pendekatan komunikatif. Tahap perencanaan pembelajaran berbicara dengan menggunakan pendekatan komunikatif pada siklus kesatu menempuh rangkaian kegiatan berikut: 1) Tim peneliti merefleksi situasi dan pokok-pokok yang tidak diharapkan pada pembelajaran sebelumnya, 2) peneliti menyusun rencana pelaksanaan pembelajaran yang digunakan rambu-rambu dalam mengembangkan kompetensi berbicara dengan menggunakan pendekatan komunikatif, dengan mempertimbangkan hasil refleksi awal, 3) menyusun dan memvalidasi instrumen yang diperlukan. Deskripsi mengenai setiap komponen rencana pelaksanaan pembelajaran yang digunakan rambu-rambu dalam mengembangkan berbicara dengan menggunakan pendekatan komunikatif. Pada tahap ini peneliti mempersiapkan perangkat pembelajaran yang terdiri dari rencana pelajaran 1 , soal tes formatif 1 dan alat-alat pengajaran yang mendukung. Obsrvasi dilakukan untuk mengetahui bagaimana langkah-langkah guru dalam melaksanakan pembelajaran. Di 
samping itu dilakukan pula observasi terhadap kegiatan siswa untuk mengetahui bagaimana minat dan aktivitas siswa dalam mengikuti pembelajaran. Kemampuan dan aktivitas guru pada proses pembelajaran siklus I yang didasarkan pada hasil pengamatan/penilaian kemampuan guru dengan menggunakan lembar pelaksanaan pembelajaran.Observasi terhadap aktivitas guru pada siklus 1 mengenai guru mengondisikan siswa agar siap belajar dapat nilai 53, lalu guru menyiapkan alat bantu dalam pembelajaran dapat point 73, guru menanyakan kepada siswa mengenai pengertian materi pelajaran dapat nilai 70 , selanjutnya menyampaikan tujuan pembelajaran yang harus dicapai dapat nilai 75 , dan guru memotivasi siswa dapat nilai 67. Maka rata-ratanya 67,6 .Untuk tahap inti kemampuan guru dalam memberikan kata kunci yang berkaitan dengan materi dapat nilai 60, guru memberi contoh berita dapat nilai 73 , guru menyampaikan materi pembelajaran dapat nilai 70 , guru memberi umpan balik dapat nilai 68 , sedangkan guru memfasilitasi siswa untuk refleksi dapat nilai 70. Maka rata-ratanya adalah 68,2 . Untuk tahap akhir, guru bersama siswa menyimpulkan dapat nilai 73 , guru mengadakan evaluasi dapat 76 , menilai dan memeriksa hasil dapat 75 , memberi tindak lanjut dapat nilai 71 , sedangkan guru dalam menginformasikan rencana pembelajaran berikutnya dapat nilai 68. Jadi rata-ratanya ada 72,6. Maka rata-rata keseluruhan pada siklus 1 mengenai pengamatan aktivitas guru adalah 69,33. Selanjutnya pengamatan terhadap aktivitas siswa dalam siklus I adalah: 1) Kemampuan siswa dalam memusatkan perhatian terhadap pembelajaran yang dilaksanakan dapat nilai 2;2) Motivasi siswa untuk mengikuti pembelajaran berbicara dapat nilai 3;3) Kemampuann siswa dalam menyimak dan memahami penjelasan langkah-langkah belajar dan tujuan pembelajaran dapat nilai 3; 4) Antusias dalam mempersiapkan diri untuk mengikuti pembelajaran berbicara dengan menggunakan pendekatan komunikatif dapat nilai 2 ; 5) Memperlihatkan penjelasan guru mengenai langkah-langkah menyampaikan persetujuan dengan menggunakan pendekatan komunikatif dapat nilai 2; 6) Kemampuan siswa fokus dan aktif menyampaikan persetujuan dengan menggunakan pendekatan komunikatif dapat nilai 2; 7) Kemampuan siswa menyelesaikan tugas tepat waktu dapat nilai 4 ; 8) Keberanian siswa bertanya mengenai materi yang kurang/belum jelas dapat nilai 3; 9) Kemampuan siswa dalam menjawab pertanyaan yang disebutkan guru dapat nilai 4; 10) Kemampuan siswa dalam menyimpulkan materi menyampaikan persetujuan dengan menggunakan pendekatan komunikatif dapat nilai 3. Jadi mencapai rata-rata 2,8 atau mencapai $70 \%$. Rata-rata nilai dan prosentasenya menunjukkan kategori kurang. Berikutnya hasil belajar siswa mengenai materi berlatih praktik debat pada siklus I dapat diketahui bahwa nilai terendah 62 , nilai tertinggi 86 , sedangkan ketuntasan mencapai $71,82 \%$, nilai rata-rata kelas sebesar 73,17

Pada pertemuan siklus II peneliti melakukan perbaikan-perbaikan. Pada akhir proses belajar mengajar siswa diberi tes formatif II dengan tujuan untuk mengetahui tingkat keberhasilan siswa dalam proses belajar mengajar yang telah dilakukan. Instrumen yang digunakan adalah tes formatif II. Kemampuan dan aktivitas guru pada proses pembelajaran siklus II yang didasarkan pada hasil pengamatan/penilaian kemampuan guru dengan menggunakan lembar pelaksanaan pembelajaran. Adapun data hasil observasi terhadap aktivitas guru adalah: 1) Guru mengondisikan siswa agar siap belajar dengan nilai 78; 2) Guru menyiapkan alat bantu dalam pembelajaran dapat nilai 83; 3) Guru menanyakan kepada siswa mengenai pengertian materi pelajaran dapat nilai 85; 4) Menyampaikan tujuan pembelajaran yang harus dicapai pada pertemuan sekarang dapat 87 ; 5) Guru memotivasi siswa dapat 80 ; 6)Kemampuan guru dalam memberikan kata kunci yang 
berkaitan dengan materi dapat nilai 75; 7) Guru memberi contoh berita dapat nilai 78; 8) Kemampuan guru dalam menyampaikan materi pembelajaran dapat nilai 85; 9) Kemampuan guru dalam menyampaikan materi pembelajaran dapat nilai 86; 10) Kemampuan guru dalam memfasilitasi siswa melakukan refleksi untuk memperoleh pengalaman belajar yang dilakukan dapat nilai 85 ; 11) Siswa bersama-sama dengan guru menyimpulkan materi dapat nilai 83 ; 12) Guru mengadakan evaluasi dapat nilai 86; 13) Guru memeriksa dan menilai hasil evaluasi dapat nilai 80;14) Memberikan tindak lanjut dengan memberikan tugas di rumah dapat 79; 15) Menginformasikan rencana pembelajaran untuk pertemuan berikutnya dapat nilai 88. Maka mendapatkan nilai keseluruhan dengan rata-rata 81,63. Sedangkan hasil observasi dan penilaian observer terhadap aktivitas siswa dalam siklus II adalah : 1) Kemampuan siswa dalam memusatkan perhatian terhadap pembelajaran yang dilaksanakan dapat nilai 4; 2) Motivasi siswa untuk mengikuti pembelajaran berbicara dapat nilai 4; 3) Kemampuann siswa dalam menyimak dan memahami penjelasan langkahg-langkah belajar dan tujuan pembelajaran dapat nilai 4; 4) Antusias dalam mempersiapkan diri untuk mengikuti pembelajaran berbicara dengan menggunakan pendekatan komunikatif dapat nilai 4; 5) Memperlihatkan penjelasan guru mengenai langkah-langkah menyampaikan persetujuan dengan menggunakan pendekatan komunikatif dapat nilai 4; 6) Kemampuan siswa fokus dan aktif menyampaikan persetujuan dengan menggunakan pendekatan komunikatif dapat nilai 4; 7) Kemampuan siswa menyelesaikan tugas tepat waktu dapat nilai 3; 8) Keberanian siswa bertanya mengenai materi yang kurang/belum jelas dapat nilai 3; 9) Kemampuan siswa dalam menjawab pertanyaan yang disebutkan guru dapat nilai 4; 10) Kemampuan siswa dalam menyimpulkan materi menyampaikan persetujuan dengan menggunakan pendekatan komunikatif dapat nilai 4. Jumlah nilai yang terakumulasi adalah 38 , dengan rata-rata nilai 3,8. Apabila dipresenrasekan mencapai 95\%. Rata-rata nilai dan presentasenya menunjukkan kategori sangat baik. Berikutnya hasil belajar siswa mengenai materi berlatih praktik debat pada siklus II dapat diketahui bahwa nilai terendah 68, nilai tertinggi 94, sedangkan ketuntasan mencapai $89,52 \%$, nilai rata-rata kelas sebesar 84,15

\section{Pembahasan}

Berdasarkan hasil survey diperoleh gambaran bahwa hasil observasi dan analisis terhadap aktivitas guru dalam pembelajaran siklus I dalam berlatih praktik debat masih rendah. Guru belum menampakkan hasil yang menggembirakan pada siswa. Berikut perbandingan rata-rata aktivitas guru siklus I dengan siklus II.

Tabel 1. Hasil Perbandingan rata-rata aktivitas guru siklus I dan II

\begin{tabular}{lccc}
\hline No & $\begin{array}{c}\text { Skor Rata-rata Aktivitas } \\
\text { Guru Siklus I }\end{array}$ & $\begin{array}{c}\text { Skor Rata-rata Aktivitas } \\
\text { Guru siklus II }\end{array}$ & Keterangan \\
\hline 1. & 69,33 & 81,63 & Meningkat \\
\hline
\end{tabular}

Dari tabel diatas dapat diperoleh data bahwa hasil observasi pada siklus I sebesar 69,33 dan pada siklus II sebesar 81,63. Dari data tersebut menunjukkan adanya kenaikan kinerja guru secara dinamis dari siklus I dan siklus II. Guru berusaha memperbaiki kekurangan -kekurangan dalam proses pembelajaran dari guru mengondisikan siswa agar siap menerima pelajaran sampai guru menginformasikan rencana pembelajaran untuk pertemuan berikutnya. Hasil observasi terhadap kinerja guru dalam menerapkan metode 
pembelajaran yang komunikatif dari satu siklus ke siklus berikutnya telah menunjukkan bahwa kinerja guru sudah baik. Pada siklus I guru sudah melaksanakan seluruh langkahlangkah pembelajaran yang telah disusun, namun belum secara maksimal karena masih ada beberapa langkah yang belum dilakukan secara baik. Pada siklus II kinerja guru semakin baik. Hal tersebut ditunjukkan dengan sudah dilakukannya langkah-langkah pembelajaran secara maksimal. Berdasarkan hasil survei awal, diperoleh gambaran bahwa aktivitas siswa dalam pembelajaran berlatih praktik debat masih rendah.Siswa kurang tertarik dengan debat dan pembelajarannya. Pada pengamatan siklus berikutnya aktivitas siswa dalam pembelajaran berlatih praktik debat mengalami peningkatan. Kemampuan siswa selama proses pembelajaran mengalami peningkatan. Aktivitas siswa dalam pembelajaran dipantau dengan lembar observasi / pengamatan. Berikut merupakan table tentang gambaran adanya peningkatan aktivitas siswa.

Tabel 2. Hasil Perbandingan Rata-rata Aktivitas Siswa Siklus I dan Suklus II

\begin{tabular}{cccc}
\hline No & $\begin{array}{c}\text { Skor Rata-rata Aktivitas } \\
\text { Siswa Siklus I }\end{array}$ & $\begin{array}{c}\text { Skor Rata-rata Aktivitas } \\
\text { Siswa siklus II }\end{array}$ & Keterangan \\
\hline 1. & 70 & 95 & Meningkat \\
\hline
\end{tabular}

Berikut merupakan gambaran perbandingan nilai rata-rata yang diperoleh siswa pada siklus I dan siklus II yang mengalami peningkatan.

Tabel 3. Hasil Perbandingan Nilai Siswa Siklus I dan Siklus II

\begin{tabular}{clccl}
\hline No. & Uraian & Siklus I & Siklus II & Keterangan \\
\hline 1. & Nilai Terendah & 62 & 68 & Meningkat \\
2. & Nilai Tertinggi & 86 & 94 & Meningkat \\
3. & Rata-rata & 73,17 & 84,15 & Meningkat \\
4. & Ketuntasan (\%) & 71,82 & 89,52 & Meningkat \\
\hline
\end{tabular}

Berdasarkan hasil perolehan nilai pada mata pelajaran bahasa Indonesia diketahui bahwa telah terjadi peningkatan hasil belajar dari siklus I rata-rata kelas 73,17 meningkat menjadi 84,15 pada siklus II. Ketuntasan belajar siswa meningkat dari $71,82 \%$ pada siklus I meningkat menjadi $89,52 \%$ pada siklus II, sehingga perbaikan pembelajaran cukup pada siklus II ini, dan tidak perlu diadakan perbaikan pada siklus III. Pembahasan dalam penelitian merupakan hasil observasi selama penelitian berdasarkan nilai atau hasil perbaikan pembelajaran, pengamatan selama proses perbaikan pembelajaran pada siklus I maupun siklus II berlangsung. Penelitian tindakan kelas ini dilaksanakan untuk kemudian dilakukan refleksi secara keseluruan pada tiap-tiap siklusnya. Pembelajaran yang dilakukan guru dengan sedemikian rupa diharapkan dapat membawa perubahan kearah yang lebih baik. Pembelajaran dengan menggunakan metode pembelajaran komunikatif dapat dijadikan salah satu alternatif untuk meningkatkan aktivitas siswa serta pemahamannya terhadap mata pelajaran, sehingga pembelajaran yang berlangsung dapat menjadi lebih baik dan diperoleh secara maksimal. Penggunaan metode/ pendekatan komunikatif dapat meningkatkan aktivitas siswa dan hasil belajar siswa dalam Bahasa Indonesia. Kelas X IPS 1 semester 1 Tahun Pelajaran 2019-2020 SMA Negeri 1 Gemolong. Pada siklus II ini 
siswa diberikan pembelajaran berlatih praktik debat dengan tetap menerapkan pembelajaran yang komunikatif tetapi diiringi dengan beberapa perbaikan. Peran guru dalam melakukan pengawasan dan pengontrolan lebih diperhatikan. Pada siklus II mengalami peningkatan kualitas proses dan hasil pembelajaran. Nilai yang diperoleh di siklus II meningkat sebanyak 32 anak atau 89,52\% sudah mencapai KKM atau peningkatan sangat besar yaitu sebesar $17,70 \%$ dari siklus I. Peserta didik yang belum tuntas masih 4 anak sehingga pembelajaran berlatih praktik debat ditujukan pada siklus II

\section{Simpulan dan Saran}

Berdasarkan hasil penelitian dan pembahasan, maka disimpulkan beberapa hal seperti berikut. Penerapan metode komunikatif dalam pembelajaran berlatih praktik debat pada kelas X IPS 1 SMA Negeri 1 Gemolong dapat meningkatkan aktivitas siswa dalam mengikuti kegiatan belajar mengajar. Siswa antusias dalam mengikuti pembelajaran karena secara langsung siswa dilibatkan. Terdapat peningkatan kemampuan siswa dalam berbicara setelah mengikuti pembelajaran dengan menggunakan pendekatan komunikatif secara signifikan. Dengan kata lain siswa mampu memenuhi indikator: (1) Mampu menentukan mekanisme diskusi; (2) Mampu menyampaikan persetujuan, sanggahan, dan penolakan pendapat dalam diskusi dengan etika yang baik dan argumentatif. Terdapat peningkatan aktivitas guru dalam pembelajaran. Sehingga mengakibatkan nilai siswa juga bagus. Berdasarkan simpulan di atas peneliti mengajukan saran yakni para guru hendaknya menggunakan metode komunikatif dalam pembelajaran lainnya sehingga siswa bisa mengalami ketuntasan belajar secara nyata dan meningkat. Para siswa memperoleh hasil maksimal dengan menggunakan pendekatan komunikatif. Dengan demikian maka diharapkan pendekatan komunikatif mampu dijadikan sebagai hasil perubahan siswa.

\section{Daftar Rujukan}

Aqib, Zainal. (2013). Model-model Media dan Strategi Pembelajaran Kontekstual (Inovatif). Bandung: Yrama Widia.

Arikunto, Suharsimi. (2006). Penelitian Tindakan Kelas. Jakarta: Bumi Aksara.

Asrori, Mohammad. (2008). Psikologi Pembelajaran. Bandung: CV Wacana Prima

Azies, dan Alwasilah. (1996). Pengajaran Bahasa Komunikatif Teori dan Praktik. Bandung: Remaja Rosdakarya.

Depdiknas. (2004). Standar Kompetensi Mata Pelajaran Bahasa dan Sastra Indonesia Sekolah Menengah Atas. Jakarta: Depdiknas

Dimyati dan Mudjiono. (2002). Belajar dan Pembelajaran. Jakarta: PT Rineka Cipta. Djiwandono, M. Soenardi. (1996). Tes Bahasa dalam Pengajaran. Bandung: ITB Bandung Giyono. (2019). Penerapan Metode Group Investigation untuk Meningkatkan Motivasi dan Kemampuan Menganalisis Teks Negosiasi Peserta Didik Kelas X MIPA 1 SMA Negeri 1 Gemolong Tahun Pelajaran 2018/2019. Jurnal Pendidikan. Volume 28 Nomor 1, Maret 2019. 1-16. Sukoharjo : LPPM Univet Bantara Press.

Hymes, Dell. (1974). Foundations in Socialinguistics : An Ethnographic Approach. Philadelphia: Universtity of Pennesylvania Press.

Syafi'i, Imam. (1996). Terampil Berbahasa Indonesia I Petunjuk Guru Bahasa Indonesia. Jakarta : Departemen Pendidikan dan Kebudayaan. 
Tarigan, Henry Guntur. (1986). Berbicara Sebagai Suatu Keterampilan Berbahasa. Bandung : Angkasa.

Triman. (2017). Upaya Meningkatkan Hasil Belajar Penjasorkes melalui Permainan Kasbol pada Siswa Kelas IV SD N Bulakrejo 01 Kecamatan Sukoharjo Kabupaten Sukoharjo Tahun Pelajaran 2016/2017.Jurnal Pendidikan. Volume 26 Nomor 2. Juli 2017. 215-224. Sukoharjo : LPPM Univet Bantara Press. 